\title{
SYSTEM SAFETY MODEL RELATED TO CLIMATE-WEATHER CHANGE PROCESS APPLICATION TO PORT AND MARITIME TRANSPORT
}

\section{ZASTOSOWANIA MODELU BEZPIECZEŃSTWA SYSTEMU PODDANEGO PROCESOWI ZMIAN KLIMATYCZNO-POGODOWYCH W TRANSPORCIE PORTOWYM I MORSKIM}

\author{
Mateusz Torbicki \\ Gdynia Maritime University
}

\begin{abstract}
The conditional safety functions at the climate-weather particular states and the unconditional safety functions of the port oil piping transportation system area and the maritime ferry, the mean values and the variances of those systems unconditional lifetimes and other safety indicators are determined. Those safety indicators, considering impact of the climate-weather change process, are evaluated for the piping system operating at under water Baltic sea area and for the maritime ferry operating at Gdynia Port area.
\end{abstract}

Keywords: safety, critical infrastructure, climate-weather change process

Streszczenie: Warunkowe funkcje bezpieczeństwa $w$ poszczególnych stanach klimatyczno-pogodowych $i$ bezwarunkowe funkcje bezpieczeństwa portowego system transport ropy oraz technicznego systemu promu morskiego, wartości średnie $i$ wariancje bezwarunkowego czasu życia tych systemów oraz inne wskaźniki bezpieczeństwa sa wyznaczone. Te wskaźniki bezpieczeństwa, rozwazając wplyw procesu zmian klimatyczno-pogodowych, sa oszacowane dla dla portowego system transportu ropy $w$ obszarze operacyjnym pod wodami Battyku oraz dla technicznego systemu promu morskiego, którego obszarem operacyjnym jest port w Gdyni.

Stowa kluczowe: bezpieczeństwo, infrastruktura krytyczna, proces zmian klimatyczno-pogodowych 
System safety model related to climate-weather change process application... Zastosowania modelu bezpieczeństwa systemu poddanego procesowi zmian...

\section{Introduction}

The paper is devoted to safety evaluation of the port oil piping transportation system and the maritime ferry technical system operating respectively at under water Baltic Sea area and Gdynia Port area. In this evaluations, the variable in time climate-weather conditions may have destructive impact on the considered systems safety. The methods applied are described in [6].

\section{Safety of port oil piping transportation system}

\section{Port oil piping transportation system description}

The port oil piping transportation system consists of three subsystems S1, S2 and S3. To simplicity our consideration, only safety of the subsystem S1 will be analyzed. The subsystem S1 is composed of two identical pipelines, each composed of 176 pipe segments of length $12 \mathrm{~m}$ and two valves. Its underwater part is presented in Figure 1.

\section{Safety of piping subsystem without consideration climate-weather impact}

The following safety states of piping transportation system are distinguished: a safety state 2 - piping operation is fully safe, a safety state 1 - piping operation is less safe and more dangerous because of the possibility of environment pollution, a safety state 0 - piping is destroyed.

The intensities of the departure from the safety states subset $\{1,2\},\{2\}$, for components of the subsystem S1 without of the climate-weather impact on their safety are as follows:

$$
\begin{aligned}
\lambda_{i j}^{(1)}(1) & =0.00002, \lambda_{i j}^{(1)}(2)=0.00003, \\
\mathrm{i} & =1,2, \quad \mathrm{j}=1, \ldots, 176, \\
\lambda_{i j}^{(1)}(1) & =0.00005, \lambda_{i j}^{(1)}(2)=0.00006, \\
\mathrm{i} & =1,2, \quad \mathrm{j}=177,178 .
\end{aligned}
$$

Taking into account the subsystem S1 is a three-state series-parallel system, its safety function without consideration climate-weather impact is given by:

$\left[\boldsymbol{S}^{(1)}(t, \cdot)\right]=\left[1, \boldsymbol{S}^{(1)}(t, 1), \boldsymbol{S}^{(1)}(t, 2)\right], \boldsymbol{S}^{(1)}(t, u)=1-\prod_{i=1}^{2}\left[1-\prod_{j=1}^{178} S_{i j}^{(1)}(t, u)\right], t \geq 0, u=1,2,(2)$

where in particular

$$
\begin{gathered}
\mathrm{S}(1)(\mathrm{t}, 1)=2 \exp [-0.00362 \mathrm{t}]-\exp [-0.00724 \mathrm{t}], \mathrm{t} \geq 0 \\
\mathrm{~S}(1)(\mathrm{t}, 2)=2 \exp [-0.0054 \mathrm{t}]-\exp [-0.0108 \mathrm{t}], \mathrm{t} \geq 0
\end{gathered}
$$




\section{Climate-weather change process at underwater piping subsystem operating area}

Taking into account the experts opinions, there are 2 parameters that describe the climate-weather states for subsystem S1 operating area:

$-\mathrm{w} 1$ - the wave height measured in meters,

- w2 - the wind speed measured in meters per second.

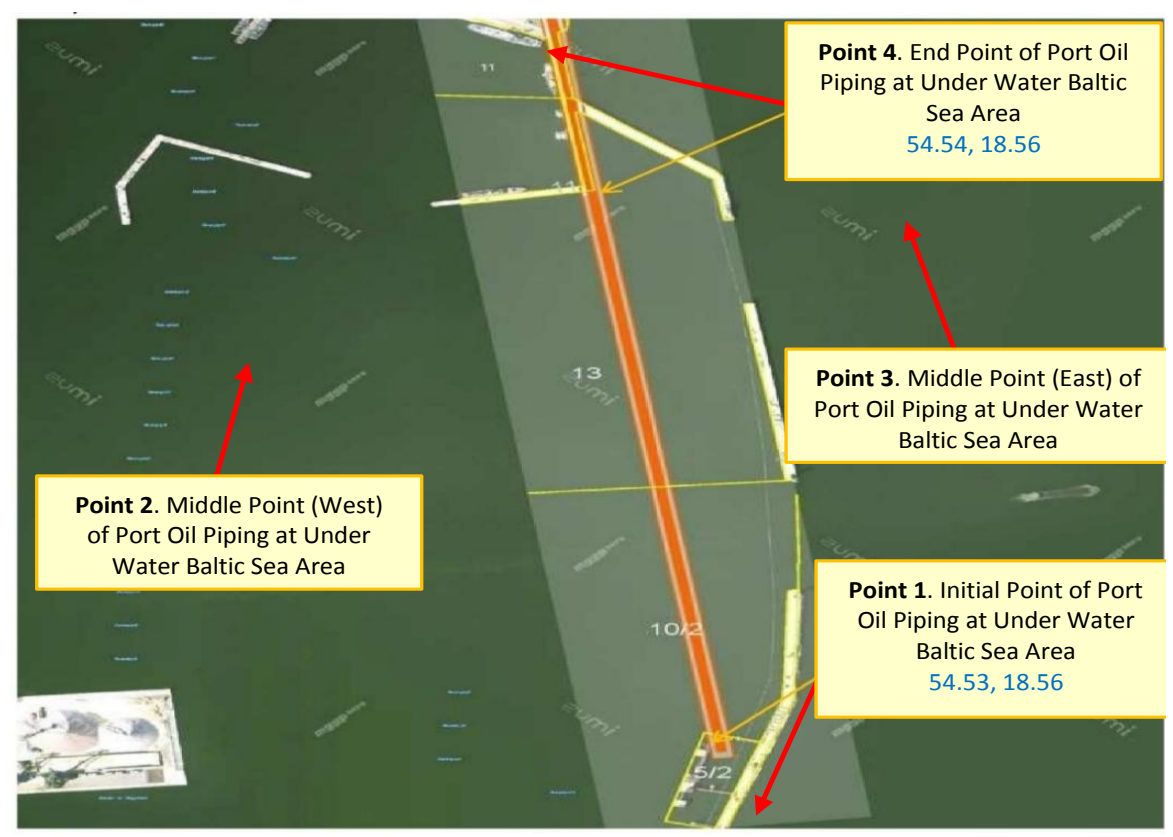

Fig. 1 The underwater part of the port oil piping transportation subsystem S1

We distinguish the following $\mathrm{w}=6$ climate-weather states:

- the climate-weather state $\mathrm{c} 1$ - the wave height from $0 \mathrm{~m}$ up to $2 \mathrm{~m}$ and the wind speed from $0 \mathrm{~m} / \mathrm{s}$ up to $17 \mathrm{~m} / \mathrm{s}$;

- the climate-weather state $\mathrm{c} 2$ - the wave height from $2 \mathrm{~m}$ up to $5 \mathrm{~m}$ and the wind speed from $0 \mathrm{~m} / \mathrm{s}$ up to $17 \mathrm{~m} / \mathrm{s}$;

- the climate-weather state $\mathrm{c} 3$ - the wave height from $5 \mathrm{~m}$ up to $14 \mathrm{~m}$ and the wind speed from $0 \mathrm{~m} / \mathrm{s}$ up to $17 \mathrm{~m} / \mathrm{s}$;

- the climate-weather state $\mathrm{c} 4$ - the wave height from $0 \mathrm{~m}$ up to $2 \mathrm{~m}$ and the wind speed from $17 \mathrm{~m} / \mathrm{s}$ up to $33 \mathrm{~m} / \mathrm{s}$;

- the climate-weather state $\mathrm{c} 5$ - the wave height from $2 \mathrm{~m}$ up to $5 \mathrm{~m}$ and the wind speed from $17 \mathrm{~m} / \mathrm{s}$ up to $33 \mathrm{~m} / \mathrm{s}$;

- the climate-weather state c6 - the wave height from $5 \mathrm{~m}$ up to $14 \mathrm{~m}$ and the wind speed from $17 \mathrm{~m} / \mathrm{s}$ up to $33 \mathrm{~m} / \mathrm{s}$.

According to expert opinions, climate-weather state c6 have the most dangerous influence on the subsystem S1 safety. 
System safety model related to climate-weather change process application... Zastosowania modelu bezpieczeństwa systemu poddanego procesowi zmian...

The climate-weather statistical data from all measurement points marked in Figure 2 are analyzed in [2]:

- the climate-weather change semi-Markov process $\mathrm{C}(\mathrm{t})$ is defined,

- the following climate-weather change process parameters are identified:

a) the vector of the initial probabilities $q b(0), b=1,2, \ldots, 6$, of the climateweather change process staying at the particular state $\mathrm{cb}$ at the moment $\mathrm{t}=0$,

b) the matrix of the probabilities qbl, b, $1=1,2, \ldots, 6, b \neq l$, of the climateweather change process transitions from the climate-weather state cb into the climate-weather state cl,

c) the matrix of the distribution functions $\mathrm{Cbl}(\mathrm{t}), \mathrm{b}, 1=1,2, \ldots, 6, b \neq 1$, of the conditional sojourn times $\mathrm{Cbl}$ of the climate-weather change process at the climate-weather states,

- the climate-weather change process $\mathrm{C}(\mathrm{t})$ limit transient probabilities at the climate-weather states $\mathrm{cb}, \mathrm{b}=1, \ldots, 6$, are evaluated by:

$$
q_{1} \cong 0.882, q_{2} \cong 0.094, q_{3} \cong 0.002, q_{4} \cong 0.005, q_{5} \cong 0.013, q_{6} \cong 0.004
$$

\section{Safety of piping subsystem S1 with consideration climate-weather impact}

Taking into account the experts opinions, the conditions at the climate-weather state c6 of the climate-weather change process at the underwater subsystem S1 operating area has a destructive influence on the safety of the components: $E_{11}^{(1)}, E_{12}^{(1)}, \ldots, E_{16}^{(1)}, E_{1121}^{(1)}, E_{1122}^{(1)}, E_{21}^{(1)}, E_{22}^{(1)}, \ldots, E_{26}^{(1)}, E_{2121}^{(1)}, E_{2122}^{(1)}$, and doesn't have impact on remaining components.

The ranges of this impact on the subsystem S1 components intensities of ageing at particular climate-weather states $\mathrm{cb}, \mathrm{b}=1,2, \ldots, 6$, for $\mathrm{u}=1,2$, are as follows:

$$
\left[\rho_{i j}^{\prime \prime(1)}(u)\right]^{(b)}=1.3, u=1,2, i=1,2, j=1, \ldots, 6,121,122, b=6,
$$

remaining $\left[\rho^{\prime \prime(1)}(u)\right]^{(b)}=1$.

After using (8)-(9) from [6], conditional safety functions of the subsystem S1 components related to the climate-weather influence are given by:

$$
\begin{aligned}
& {\left[S^{\prime \prime(1)}(t, 1)\right]^{(b)}=\exp [-0.000026], \quad t \geq 0, j=1, . ., 6,121,122, \quad b=6 \text {, }} \\
& {\left[S^{\prime \prime}{ }_{i j}^{(1)}(t, 1)\right]^{(b)}=\exp [-0.00002 t], \quad t \geq 0, j=1, . ., 6,121,122, \quad b=1, . ., 5 \text {, or }} \\
& j=7, . ., 120,123, . ., 176, b=1, . .6, \\
& {\left[S^{\prime \prime(1)}(t, 1)\right]^{(b)}=\exp [-0.00005 t], \quad t \geq 0, j=177,178, \quad b=1, . ., 6,} \\
& {\left[S^{\prime \prime}{ }_{i j}^{(1)}(t, 2)\right]^{(b)}=\exp [-0.000039 t], \quad t \geq 0, \quad j=1, . ., 6,121,122,} \\
& b=6 \text {, } \\
& {\left[S^{\prime \prime}{ }_{i j}^{(1)}(t, 2)\right]^{(b)}=\exp [-0.00003 t], \quad t \geq 0, j=1, . ., 6,121,122, \quad b=1, . ., 5, \text { or }} \\
& j=7, . ., 120,123, ., 176, \quad b=1, . ., 6,
\end{aligned}
$$


$\left[S^{\prime \prime(1)}(t, 2)\right]^{(b)}=\exp [-0.00006 t], t \geq 0, j=177,178$,

$b=1, \ldots, 6$.

Hence, the subsystem S1 three-state conditional safety function related to the climate-weather change process impact is as follows:

$$
\begin{aligned}
& {\left[\boldsymbol{S}^{\mathbf{\prime \prime}(1)}(t, \cdot)\right]^{(b)}=\left[1,\left[\boldsymbol{S}^{\mathbf{\prime \prime}(1)}(t, 1)\right]^{(b)},\left[\boldsymbol{S}^{\mathbf{\prime \prime}(1)}(t, 2)\right]^{(b)}\right], t \geq 0, b=1, \ldots, 6,} \\
& {\left[\boldsymbol{S}^{\mathbf{\prime \prime}(1)}(t, u)\right]^{(b)}=1-\prod_{i=1}^{2}\left[1-\prod_{j=1}^{178}\left[S^{\prime \prime}{ }_{i j}^{(1)}(t, u)\right]^{(b)}\right], t \geq 0, u=1,2, b=1, \ldots, 6 .}
\end{aligned}
$$

Next, according to (14) from [6], the unconditional safety function of the subsystem S1 operating at the underwater area, is given by

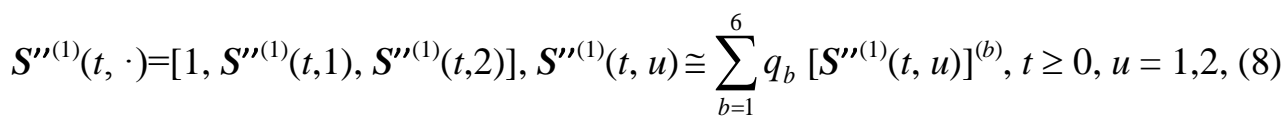

where in particular

$\mathrm{S}^{\prime \prime}(1)(\mathrm{t}, 1)=0.996 \cdot(2 \exp [-0.00362 \mathrm{t}]-\exp [-0.00724 \mathrm{t}])+0.004 \cdot(2 \exp [-0.003668 \mathrm{t}]$ $-\exp [-0.007336 \mathrm{t}]), \mathrm{t} \geq 0$,

$\mathrm{S}^{\prime \prime}(1)(\mathrm{t}, 2)=0.996 \cdot(2 \exp [-0.0054 \mathrm{t}]-\exp [-0.0108 \mathrm{t}])+0.004 \cdot(2 \exp [-0.005472 \mathrm{t}]$

$-\exp [-0.010944 \mathrm{t}]), \mathrm{t} \geq 0$,

and $\mathrm{qb}, \mathrm{b}=1, \ldots, 6$, are the climate-weather change process $\mathrm{C}(\mathrm{t})$ limit transient probabilities at the state $\mathrm{cb}, \mathrm{b}=1, \ldots, 6$, at the subsystem $\mathrm{S} 1$ operating at the underwater area, given by (1). The safety function of the considered subsystem operating at the fixed area is presented in Figure 2.

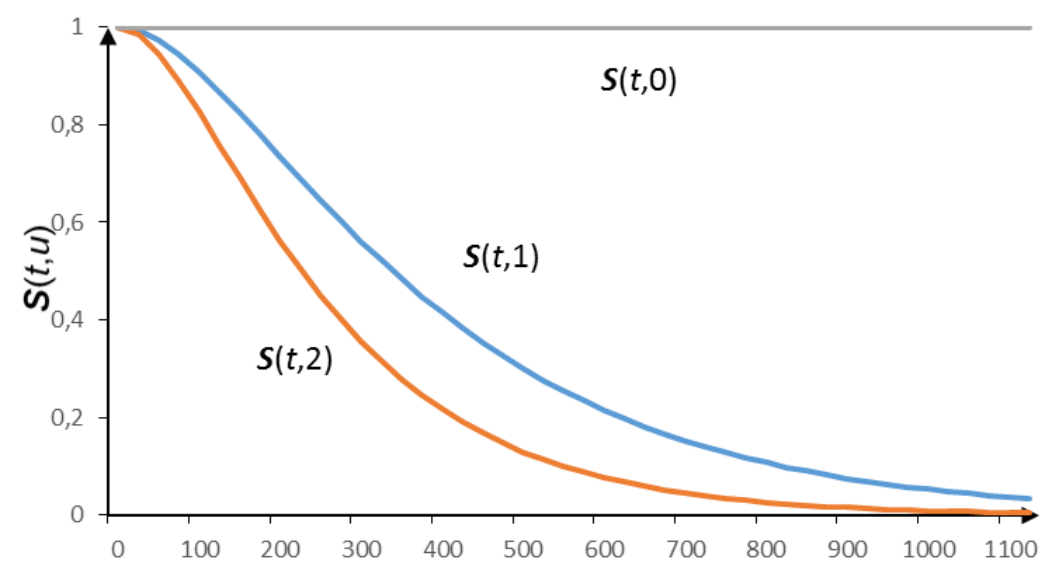

Fig. 2 The graph of the piping subsystem operating at the underwater area safety function coordinates

The expected values and standard deviations lifetimes of the piping subsystem operating at the underwater area in the safety state subsets calculated from the 
System safety model related to climate-weather change process application... Zastosowania modelu bezpieczeństwa systemu poddanego procesowi zmian...

results given by (8)-(9), according to the formulae (15)-(16) from [6], are as follows (in parenthesis are expected values and standard deviations of the piping subsystem lifetimes without considering climate-weather impact):

$\mu^{\prime \prime}(1) \cong 414.342, \mu^{\prime \prime}(2) \cong 277.762,\left(\mu(1) \cong 414.364, \mu '{ }^{\prime}(2) \cong 277.777\right)$ years, $\left.\sigma^{\prime \prime}(1) \cong 308.84, \sigma^{\prime \prime}(2) \cong 207.03, \sigma(1) \cong 308.85, \sigma(2) \cong 207.04\right)$ years.

The graphs of the intensities of ageing of the maritime ferry system with consideration climate-weather impact calculated using (21)-(22) from [6] are shown in Figure 3 and the graphs of the coefficients of the climate-weather impact on the maritime ferry system calculated using (23)-(24) from [6] are shown in Figure 4.

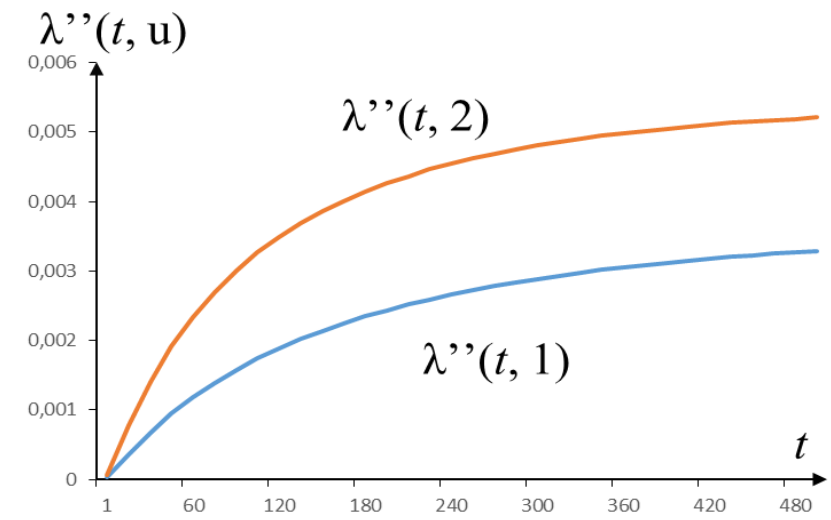

Fig. 3 The graphs of the intensities of ageing of the subsystem S1

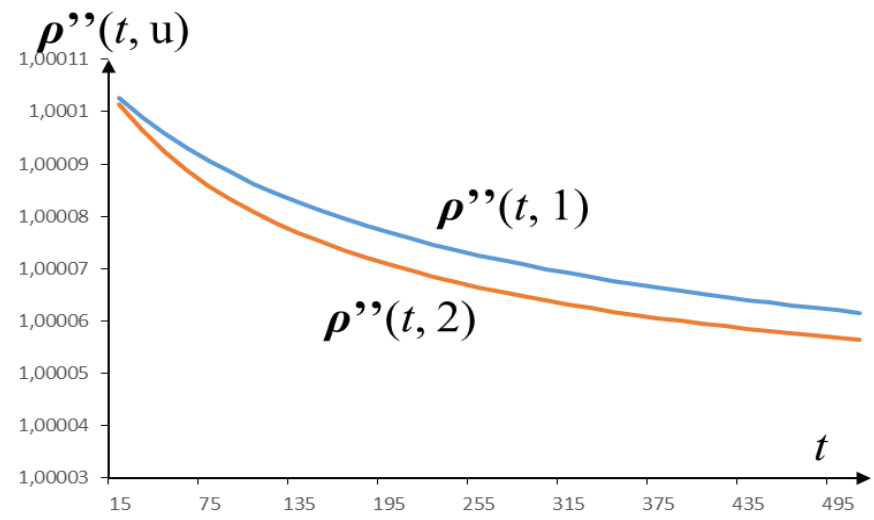

Fig. 4 Coefficients of the climate-weather impact on the subsystem S1

The coefficient of the climate-weather impact on the subsystem S1 without considering variability in time, according to (26) from [6], is equal to:

$\rho^{\prime \prime}(\mathrm{u})=\mu(\mathrm{u}) / \mu^{\prime \prime}(\mathrm{u}), \mathrm{u}=1,2$, where in particular 


$$
\rho " '(1)=1.0001, \rho "{ }^{\prime}(2)=1.0001 .
$$

Finally, the coefficient of the climate-weather resilience of the subsystem S1 without considering variability in time, according to (27) from [6], is equal to:

$$
\begin{aligned}
& \mathrm{RI}^{\prime}{ }^{\prime}(\mathrm{u})=1 / \rho \mathrm{\rho} \text { ' }(\mathrm{u}), \mathrm{u}=1,2 \text {, where in particular } \\
& \text { RI''(1) = 99.99\%, RI'’(2) = 99.99\% . }
\end{aligned}
$$

\section{Safety of maritime ferry technical system}

\section{Maritime ferry technical system description}

The maritime ferry technical system is composed of subsystems S1, S2, .., S5, presented in Figure 5.

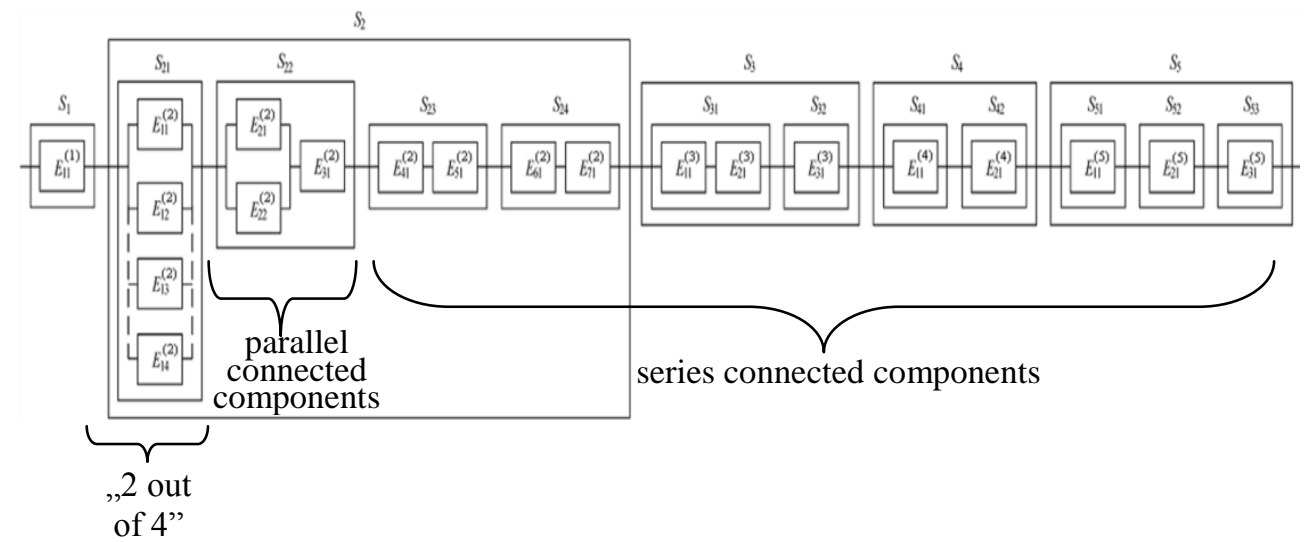

Fig. 5 The scheme of the ferry technical system structure

\section{Safety of maritime ferry system without consideration climate-weather impact}

The following safety states of maritime ferry system are distinguished:

- a safety state 4 - the ferry operation is fully safe,

- a safety state 3 - the ferry operation is less safe and more dangerous because of the possibility of environment pollution,

- a safety state 2 - the ferry operation is less safe and more dangerous because of the possibility of environment pollution and causing small accidents,

- a safety state 1 - the ferry operation is much less safe and much more dangerous because of the possibility of serious environment pollution and causing extensive accidents,

- a safety state 0 - the ferry technical system is destroyed. 
System safety model related to climate-weather change process application... Zastosowania modelu bezpieczeństwa systemu poddanego procesowi zmian...

The intensities of components $E_{i j}^{(v)}, j=1,2, \ldots, l_{i}, i=1,2, \ldots, k$, of the maritime ferry technical subsystems $S_{v}, v=1,2,3,4,5$, departure from the safety states subset $\{1,2,3,4\},\{2,3,4\},\{3,4\},\{4\}$, without of climate-weather impact on their safety are as follows:

$$
\begin{aligned}
& {\left[\lambda_{11}^{(1)}(1)\right]=0.015,\left[\lambda_{11}^{(1)}(2)\right]=0.020,\left[\lambda_{11}^{(1)}(3)\right]=0.022,\left[\lambda_{11}^{(1)}(4)\right]=0.025 ;} \\
& {\left[\lambda_{1 j}^{(2)}(1)\right]=0.02,\left[\lambda_{1 j}^{(2)}(2)\right]=0.03,\left[\lambda_{1 j}^{(2)}(3)\right]=0.04,\left[\lambda_{1 j}^{(2)}(4)\right]=0.05, j=1, \ldots, 4 ;} \\
& {\left[\lambda_{2 j}^{(2)}(1)\right]=0.015,\left[\lambda_{2 j}^{(2)}(2)\right]=0.02,\left[\lambda_{2 j}^{(2)}(3)\right]=0.025,\left[\lambda_{2 j}^{(2)}(4)\right]=0.03, j=1,2 ;} \\
& {\left[\lambda_{31}^{(2)}(1)\right]=0.01,\left[\lambda_{31}^{(2)}(2)\right]=0.015,\left[\lambda_{31}^{(2)}(3)\right]=0.02,\left[\lambda_{31}^{(2)}(4)\right]=0.025,} \\
& {\left[\lambda_{i 1}^{(2)}(1)\right]=0.01,\left[\lambda_{i 1}^{(2)}(2)\right]=0.015,\left[\lambda_{i 1}^{(2)}(3)\right]=0.02,\left[\lambda_{i 1}^{(2)}(4)\right]=0.025, i=4, \ldots, 7 ;} \\
& {\left[\lambda_{i 1}^{(3)}(1)\right]=0.010,\left[\lambda_{i 1}^{(3)}(2)\right]=0.025,\left[\lambda_{i 1}^{(3)}(3)\right]=0.030,\left[\lambda_{i 1}^{(3)}(4)\right]=0.040, i=1,2,3 ;} \\
& {\left[\lambda_{i 1}^{(4)}(1)\right]=0.015,\left[\lambda_{i 1}^{(4)}(2)\right]=0.030,\left[\lambda_{i 1}^{(4)}(3)\right]=0.045,\left[\lambda_{i 1}^{(4)}(4)\right]=0.050, i=1,2 ;} \\
& {\left[\lambda_{i 1}^{(5)}(1)\right]=0.01,\left[\lambda_{i 1}^{(5)}(2)\right]=0.02,\left[\lambda_{i 1}^{(5)}(3)\right]=0.03,\left[\lambda_{i 1}^{(5)}(4)\right]=0.04, i=1,2,3 .}
\end{aligned}
$$

\section{Climate-weather change process for maritime ferry operating at Gdynia Port area}

Taking into account the experts opinions, there are 2 parameters that describe the climate-weather states for maritime ferry operating at Gdynia Port area:

- w1 - the wind speed measured in meters per second,

- w2 - the wind direction measured in azimuth degrees.

We distinguish the following $\mathrm{w}=6$ climate-weather states:

- the climate-weather state $\mathrm{c} 1$ - the wind speed from $0 \mathrm{~m}$ up to $17 \mathrm{~m}$ and the wind direction from $0^{\circ}$ up to $22.5^{\circ}$ or from $67.5^{\circ}$ up to $112.5^{\circ}$ or from $337.5^{\circ}$ up to $360^{\circ}$;

- the climate-weather state $\mathrm{c} 2$ - the wind speed from $17 \mathrm{~m}$ up to $33 \mathrm{~m}$ and the wind direction from $0^{\circ}$ up to $22.5^{\circ}$ or from $67.5^{\circ}$ up to $112.5^{\circ}$ or from $337.5^{\circ}$ up to $360^{\circ}$;

- the climate-weather state $\mathrm{c} 3$ - the wind speed from $0 \mathrm{~m}$ up to $17 \mathrm{~m}$ and the wind direction from $22.5^{\circ}$ up to $67.5^{\circ}$ or from $112.5^{\circ}$ up to $247.5^{\circ}$;

- the climate-weather state $\mathrm{c} 4$ - the wind speed from $17 \mathrm{~m}$ up to $33 \mathrm{~m}$ and the wind direction from $22.5^{\circ}$ up to $67.5^{\circ}$ or from $112.5^{\circ}$ up to $247.5^{\circ}$;

- the climate-weather state c5 - the wind speed from $0 \mathrm{~m}$ up to $17 \mathrm{~m}$ and the wind direction from $247.5^{\circ}$ up to $337.5^{\circ}$;

- the climate-weather state c6 - the wind speed from $17 \mathrm{~m}$ up to $33 \mathrm{~m}$ and the wind direction from $247.5^{\circ}$ up to $337.5^{\circ}$.

According to expert opinions, climate-weather states c2 and c6 have the most dangerous influence on the maritime ferry technical system safety. 


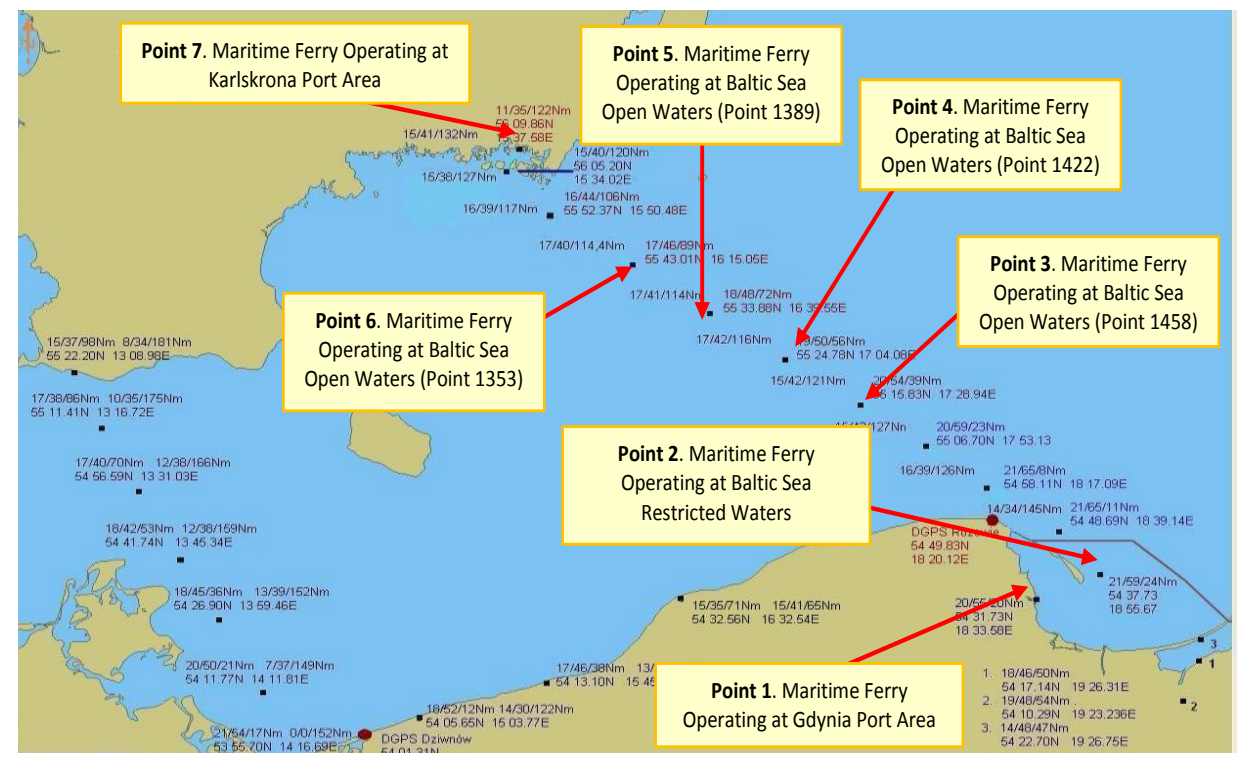

Fig. 6 Maritime ferry route between Karlskrona and Gdynia ports

The climate-weather statistical data from the first measurement point marked in Figure 6 is analyzed in [2]:

- the climate-weather change semi-Markov process $\mathrm{C}(\mathrm{t})$ is defined,

- the following climate-weather change process parameters are identified:

a) the vector of the initial probabilities $q b(0), b=1,2, \ldots, 6$, of the climateweather change process staying at the particular state $\mathrm{cb}$ at the moment $\mathrm{t}=0$,

b) the matrix of the probabilities qbl, b, $1=1,2, \ldots, 6, b \neq l$, of the climateweather change process transitions from the climate-weather state cb into the climate-weather state cl,

c) the matrix of the distribution functions $\mathrm{Cbl}(\mathrm{t}), \mathrm{b}, \mathrm{l}=1,2, \ldots, 6, \mathrm{~b} \neq 1$, of the conditional sojourn times $\mathrm{Cbl}$ of the climate-weather change process at the climate-weather states,

- the climate-weather change process $\mathrm{C}(\mathrm{t})$ limit transient probabilities at the climate-weather states $\mathrm{cb}, \mathrm{b}=1, \ldots, 6$, are evaluated by:

$$
q_{1} \cong 0.404, q_{2} \cong 0.011, q_{3} \cong 0.451, q_{4} \cong 0.010, q_{5} \cong 0.124, q_{6} \cong 0 .
$$

\section{Safety of maritime ferry system with consideration climate-weather impact}

Taking into account the experts opinions, the conditions at climate-weather states c2, c6 of the climate-weather change process at the maritime ferry operating area in Gdynia Port has a destructive influence on the safety of the ferry technical subsystem S1, S2 and doesn't have impact on subsystem S3, S4 and S5 safety. 
System safety model related to climate-weather change process application... Zastosowania modelu bezpieczeństwa systemu poddanego procesowi zmian...

The ranges of this impact on the ferry components intensities of ageing at particular climate-weather states $\mathrm{cb}, \mathrm{b}=1,2, \ldots, 6$, for $\mathrm{u}=1, \ldots, 4$, are as follows:

$$
\begin{aligned}
& {\left[\rho_{11}^{\prime \prime(1)}(u)\right]^{(b)}=1.05, b=2,6,\left[\rho_{1 j}^{\prime \prime(2)}(u)\right]^{(b)}=1.1, b=2,6, j=1, . ., 4,} \\
& {\left[\rho_{2 j}^{\prime \prime(2)}(u)\right]^{(b)}=1.30, b=2,6, j=1,2,\left[\rho_{31}^{\prime \prime(2)}(u)\right]^{(b)}=1.30, b=2,6,} \\
& {\left[\rho_{i 1}^{\prime \prime(2)}(u)\right]^{(b)}=1.25, b=2,6, i=4,5,\left[\rho_{i 1}^{\prime \prime(2)}(u)\right]^{(b)}=1.10, b=2,6, i=6,7,} \\
& \text { and remaining }\left[\rho^{\prime \prime}{ }_{i j}^{(k)}(u)\right]^{(b)}=1 .
\end{aligned}
$$

Finally, the maritime ferry five-state conditional safety function related to the climate-weather change process influence at the fixed operating area is given as follows (it is calculated in [3]):

$$
\left[\mathrm{S}^{\prime \prime}(\mathrm{t}, \cdot)\right](\mathrm{b})=\left[1,\left[\mathrm{~S}^{\prime \prime}(\mathrm{t}, 1)\right](\mathrm{b}), \ldots,\left[\mathrm{S}^{\prime \prime}(\mathrm{t}, 4)\right](\mathrm{b})\right], \mathrm{t} \geq 0, \mathrm{~b}=1, \ldots, 6
$$

where in particular

$\left[\mathrm{S}^{\prime \prime}(\mathrm{t}, 1)\right](\mathrm{b})=12 \exp [-0.210 \mathrm{t}]-6 \exp [-0.225 \mathrm{t}]-16 \exp [-0.230 \mathrm{t}]+8 \exp [-0.245 \mathrm{t}]$

$+6 \exp [-0.250 \mathrm{t}]-3 \exp [-0.265 \mathrm{t}], \mathrm{b}=2,6, \mathrm{t} \geq 0$,

$\left[\mathrm{S}^{\prime \prime}(\mathrm{t}, 1)\right](\mathrm{b})=-3 \exp [-0.29275 \mathrm{t}]+6 \exp [-0.27325 \mathrm{t}]+8 \exp [-0.27075 \mathrm{t}]$

$-16 \exp [-0.25125 \mathrm{t}]-6 \exp [-0.24875 \mathrm{t}]+12 \exp [-0.22925 \mathrm{t}], \mathrm{b}=1,3,4,5, \mathrm{t} \geq 0$,

$\left[S^{\prime \prime}(t, 2)\right](b)=12 \exp [-0.370 t]-6 \exp [-0.390 t]-16 \exp [-0.400 t]+8 \exp [-0.420 t]$

$+6 \exp [-0.430 \mathrm{t}]-3 \exp [-0.450 \mathrm{t}], \mathrm{b}=2,6, \mathrm{t} \geq 0$,

$\left[\mathrm{S}^{\prime \prime}(\mathrm{t}, 2)\right](\mathrm{b})=-3 \exp [-0.490 \mathrm{t}]+6 \exp [-0.464 \mathrm{t}]+8 \exp [-0.457 \mathrm{t}]-16 \exp [-0.431 \mathrm{t}]$

$-6 \exp [-0.424 \mathrm{t}]+12 \exp [-0.398 \mathrm{t}], \mathrm{b}=1,3,4,5, \mathrm{t} \geq 0$,

$\left[\mathrm{S}^{\prime}{ }^{\prime}(\mathrm{t}, 3)\right](\mathrm{b})=12 \exp [-0.497 \mathrm{t}]-6 \exp [-0.522 \mathrm{t}]-16 \exp [-0.537 \mathrm{t}]+8 \exp [-0.562 \mathrm{t}]$

$+6 \exp [-0.577 \mathrm{t}]-3 \exp [-0.602 \mathrm{t}], \mathrm{b}=2,6, \mathrm{t} \geq 0$,

$\left[\mathrm{S}^{\prime \prime}(\mathrm{t}, 3)\right](\mathrm{b})=-3 \exp [-0.6541 \mathrm{t}]+6 \exp [-0.6216 \mathrm{t}]+8 \exp [-0.6101 \mathrm{t}]-16 \exp [-0.5776 \mathrm{t}]$

$-6 \exp [-0.5661 \mathrm{t}]+12 \exp [-0.5336 \mathrm{t}], \mathrm{b}=1,3,4,5, \mathrm{t} \geq 0$,

$\left[\mathrm{S}^{\prime \prime}(\mathrm{t}, 4)\right](\mathrm{b})=12 \exp [-0.620 \mathrm{t}]-6 \exp [-0.650 \mathrm{t}]-16 \exp [-0.670 \mathrm{t}]+8 \exp [-0.700 \mathrm{t}]$

$+6 \exp [-0.720 \mathrm{t}]-3 \exp [-0.750 \mathrm{t}], \mathrm{b}=2,6, \mathrm{t} \geq 0$,

$\left[\mathrm{S}^{\prime \prime}(\mathrm{t}, 4)\right](\mathrm{b})=-3 \exp [-0.81425 \mathrm{t}]+6 \exp [-0.77525 \mathrm{t}]+8 \exp [-0.75925 \mathrm{t}]$

$-16 \exp [-0.72025 \mathrm{t}]-6 \exp [-0.70425 \mathrm{t}]+12 \exp [-0.66525 \mathrm{t}], \mathrm{b}=1,3,4,5, \mathrm{t} \geq 0$.

According to (14) from [6], the unconditional safety function of the ferry technical system operating at the fixed area, is given by

$S^{\prime \prime}(t, \cdot)=\left[1, S^{\prime \prime}(t, 1), \ldots, S^{\prime \prime}(t, 4)\right], S^{\prime \prime}(t, \mathrm{u}) \cong \sum_{b=1}^{6} q_{b}\left[S^{\prime \prime}(t, u)\right]^{(b)}, t \geq 0, u=1, \ldots, 4,(18)$ 
where $\mathrm{qb}, \mathrm{b}=1, . ., 6$, are the climate-weather change process $\mathrm{C}(\mathrm{t})$ limit transient probabilities at the state $c b, b=1, . .6$, at the Gdynia Port area, given by (14). The safety function of the ferry five-state technical system operating at the Gdynia Port area is presented in Figure 7.

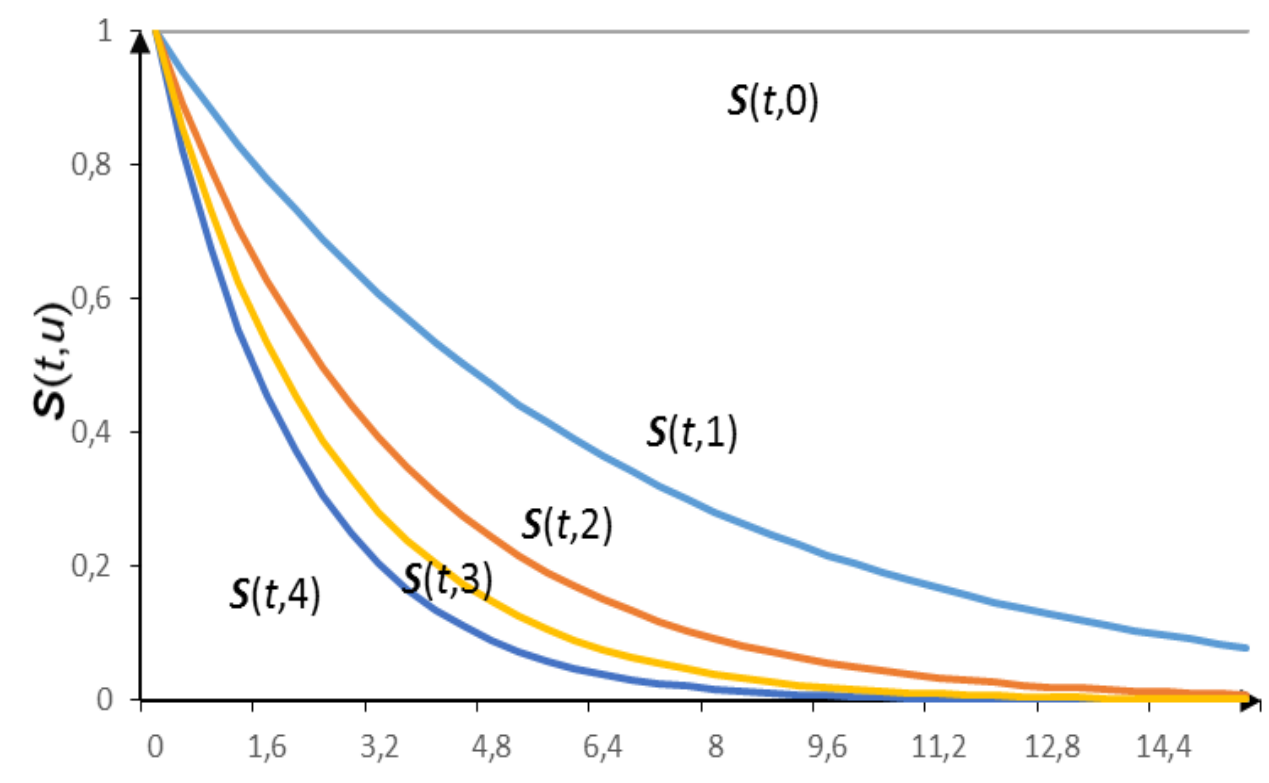

Fig. 7 The graph of the ferry technical system operating at the Gdynia Port area safety function coordinates

The expected values and standard deviations of the ferry technical system operating at the Gdynia Port area lifetimes in the safety state subsets calculated from the results given by (16)-(18), according to the formulae (15)-(16) from [6], are (in parenthesis are expected values and standard deviations of the ferry system lifetimes without considering climate-weather impact):

$\mu^{\prime \prime}(1) \cong 6.241, \mu^{\prime \prime}(2) \cong 3.388, \mu^{\prime \prime}(3) \cong 2.502, \mu^{\prime \prime}(4) \cong 2.006$ year,

$(\mu(1) \cong 6.246, \mu(2) \cong 3.390, \mu(3) \cong 2.503, \mu(4) \cong 2.007$ year $)$,

$\sigma^{\prime \prime}(1) \cong 6.030, \sigma^{\prime \prime}(2) \cong 3.30, \sigma^{\prime \prime}(3) \cong 2.45, \sigma^{\prime \prime}(4) \cong 1.96$ year,

$(\sigma(1) \cong 6.040, \sigma(2) \cong 3.31, \sigma(3) \cong 2.45, \sigma(4) \cong 1.96$ year $)$.

The graphs of the intensities of ageing of the maritime ferry system with consideration climate-weather impact calculated using (21)-(22) from [6] are shown in Figure 8 and the graphs of the coefficients of the climate-weather impact on the maritime ferry system calculated using (23)-(24) from [6] are shown in Figure 9. 
System safety model related to climate-weather change process application... Zastosowania modelu bezpieczeństwa systemu poddanego procesowi zmian...

The coefficients of the climate-weather impact on the maritime ferry without considering variability in time, according to (26) from [6], are equal to:

$$
\rho^{\prime \prime}(\mathrm{u})=\mu(\mathrm{u}) / \mu,(\mathrm{u}), \mathrm{u}=1,2, \ldots, 4,
$$

where in particular

$$
\rho^{\prime \prime}(1)=1.0008, \rho{ }^{\prime \prime}(2)=1.00059, \rho{ }^{\prime \prime}(3)=1.0004, \rho{ }^{\prime \prime}(4)=1.0005 \text {. }
$$

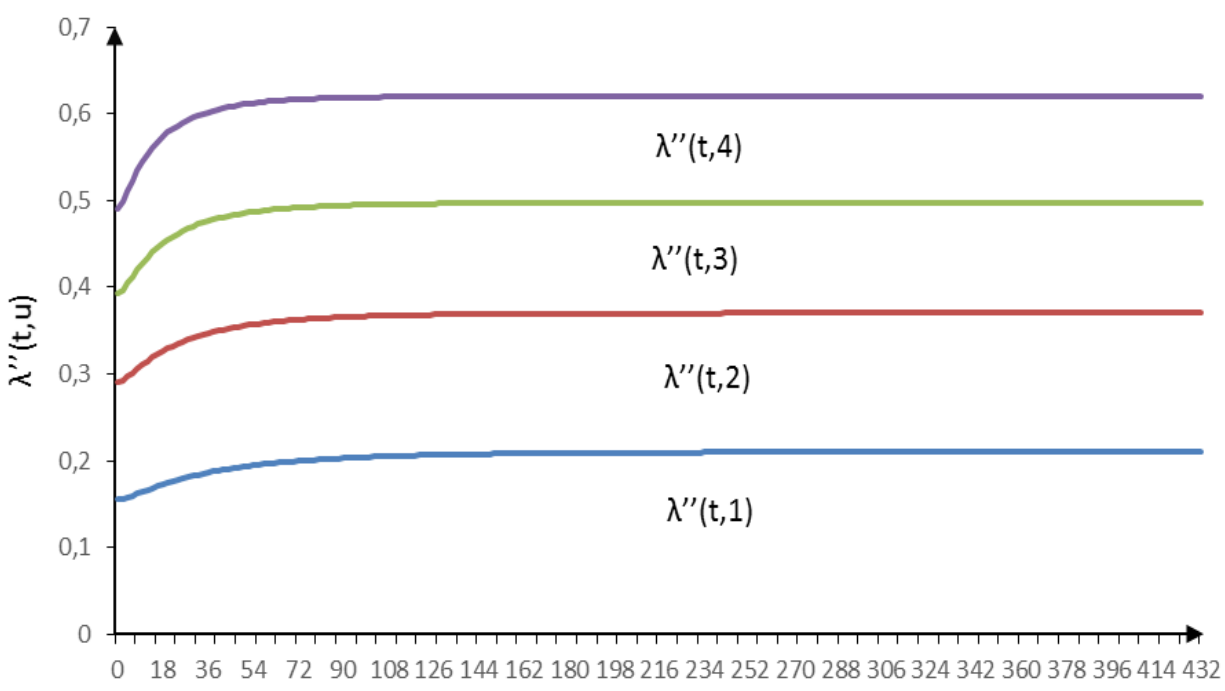

Fig. 8 The graphs of the intensities of ageing of the maritime ferry system

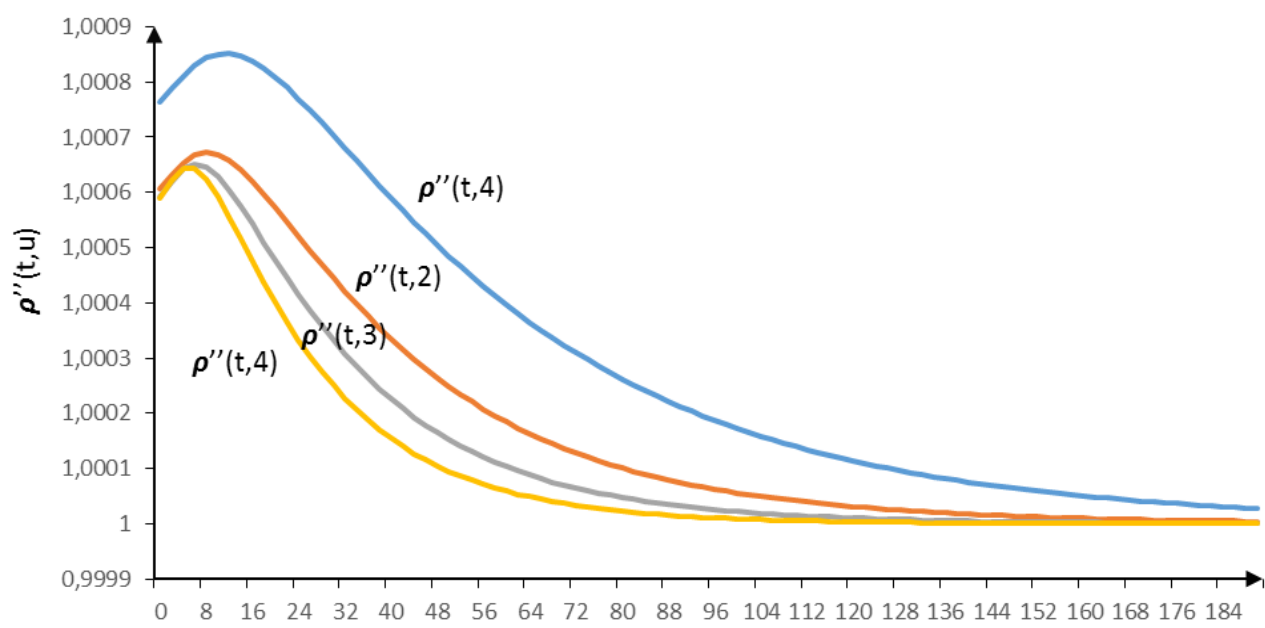

Fig. 9 Coefficients of the climate-weather impact on the maritime ferry 
Finally, the coefficients of the climate-weather resilience of the maritime ferry without considering variability in time, according to (27) from [6], are equal to:

$\mathrm{RI}^{\prime}(\mathrm{u})=1 / \rho^{\prime \prime}(\mathrm{u}), \mathrm{u}=1,2, \ldots, 4$,

where in particular

RI'(1) = 99.92\%, RI' (2) = 99.94\%, RI' (3) = 99.96\%, RI'(4) = 99.95\%.

\section{Conclusions}

The predicted safety characteristics of the piping subsystem operating at underwater Baltic Sea area and the ferry technical system operating at the Gdynia Port area at the variable climate-weather conditions are different from those determined for those systems operating at constant conditions without considering climate-weather influence [3]. This fact justifies the reasonableness of considering real systems' safety under the influence of the variable climate-weather conditions. This approach makes the safety prediction of critical infrastructures much more precise through including natural hazards.

\section{Acknowledgments}

The paper presents the results developed in the scope of the EU-CIRCLE project titled "A pan - European framework for strengthening Critical Infrastructure resilience to climate change" that has received funding from the European Union's Horizon 2020 research and innovation programme under grant agreement No 653824, http://www.eu-circle.eu/.

\section{References}

[1] EU-CIRCLE Report D3.3-GMU3-CISM: Critical infrastructure safety model (CISM) multistate ageing approach independent and dependent components and subsystems, 2016.

[2] EU-CIRCLE Report D3.3-GMU3-C-WCP: Critical infrastructure operating area climate-weather change process $(\mathrm{C}-\mathrm{WCP})$ including extreme weather hazards (EWH), 2016.

[3] EU-CIRCLE Report D3.3-GMU3-IMCIS Model3: Integrated model of critical infrastructure safety related to climate-weather change process including extreme weather hazards, 2016.

[4] Grabski F.: Semi-Markov Processes: Application in System Reliability and Maintenance, Elsevier, 2014.

[5] Kołowrocki K., Soszyńska-Budny J.: Reliability and Safety of Complex Technical Systems and Processes: Modeling - Identification - Prediction Optimization, Springer, 2011. 
System safety model related to climate-weather change process application... Zastosowania modelu bezpieczeństwa systemu poddanego procesowi zmian...

[6] Kołowrocki K., Soszyńska-Budny J., Torbicki M.: Model of system safety related to climate-weather change process, Journal of KONBiN, 2017, in prep.

[7] Limnios N., Oprisan G.: Semi-Markov Processes and Reliability, Birkhauser, Boston, 2005.

Mateusz Torbicki is an Assistant at Department of Mathematics of the Faculty of Navigation in Gdynia Maritime University. His field of interest is analysis of safety of critical infrastructures operating at changing climate-weather conditions which may have destructive impact on considered critical infrastructure components. He has published over 20 papers in scientific journals and conference proceedings. 